\title{
Fluid Inclusion Studies of Radioactive Mineralized Pegmatites at Gabal Abu Furad Area, Central Eastern Desert, Egypt
}

\author{
Essam M. Esmail and Ashraf F. Moharem \\ Nuclear Materials Authority \\ P.O. Box 530, El-Maadi, Cairo, Egypt \\ Received: $2 / 5 / 2007$ \\ Accepted: 24/11/2008
}

\begin{abstract}
Numerous unzoned and zoned pegmatite pockets are the most important types from the radioactive point of view. They occur at the marginal parts and higher topographic level of G. Abu Furad younger granites. Zoned pegmatites are composed of extremely coarse-grained milky quartz core, intermediate mica zone and wall zone of feldspars. An alteration zone is found in contact between quartz core and intermediate zone. This zone records the highest radioactive values due to its mineral composition, as a result of alteration processes associated with radioactive minerals.
\end{abstract}

The late magmatic alteration process (hematitization, kaolinitization and fluoritization) of the pegmatite resulted in the formation of martite, fluorite, clay minerals and carbonates (calcite) in the alteration zone. The circulating fluids played an important role in remobilization and concentrating uranium.

Fluid inclusion studies by microthermometry were carried out on authigenic minerals (such as quartz and fluorite) in the alteration zones. This study revealed that, at least two stages of the latemagmatic hydrothermal alteration were involved. The first stage is of high temperature low saline fluids characteristic of hematization that resulted from fluid-rock interaction with late magmatic fluids that very probably mixed with external low salinity fluids along brittle structures. The second stage is of low temperature high saline fluids that characterize the fluoritized alteration due to consequent reaction with wallrocks and mixing with meteoric water.

Mixing of low salinity meteoric water with hot ascending saline hydrothermal solution leads to $\mathrm{pH}$ change and continuous interaction with wall rock. The change in $\mathrm{pH}$ plays the main role in remobil- 
ization and precipitation of many rare metals such as $\mathrm{U}, \mathrm{Th}, \mathrm{Nb}, \mathrm{Zr}, \mathrm{Y}$ and REEs in mineral assemblages such as euxenite, zircon, carnotite, thorianite, allanite, bastnesite and fluorite. Heating of slightly saline meteoric water by convection acting on the pegmatites along shallow shear zone causes the formation of fluorite and uranium mineralization.

Keywords: Fluid Inclusion; Uranium Mineralization, Pegmatites.

\section{Introduction}

The studied area represents a part of the central Eastern Desert of Egypt; it covers about $203 \mathrm{~km}^{2}$ of crystalline basement rocks. It is bounded by latitudes $26^{\circ} 37^{\circ}$ and $26^{\circ} 43^{\circ} \mathrm{N}$ and longitudes $33^{\circ} 36^{\prime}$ and $33^{\circ} 43^{\circ} \mathrm{E}$ (Fig. 1). The area of study is located nearby the Red Sea at about $40 \mathrm{~km}$ west of Safaga city and can be reached through Qena-Safaga paved road which passes through wadi Um Tagher at the northern side of the mapped area. The main wadis occurring in the area are wadi Abu Furad, wadi Um Tagher and wadi El-Bulah that are trending in the E-W, NW$\mathrm{SE}$ and N-S directions respectively.

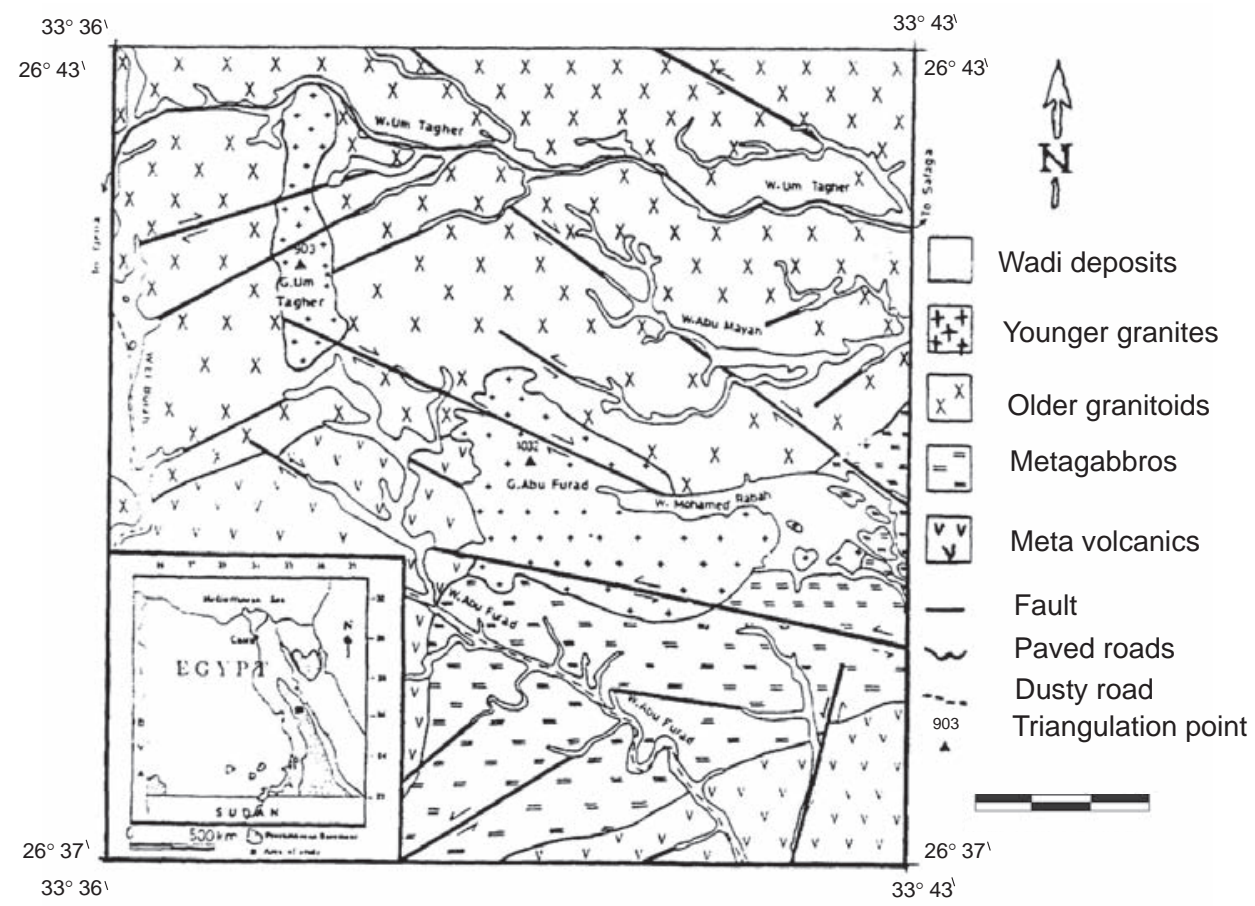

Fig. 1. Geologic map of G. Um Tagher-G. Abu Furad area. 
Based on field studies, the rocks cropping out in the area are: 1) Metavolcanics (oldest), 2) metagabbros, 3) older granitoids, and 4) younger granites (youngest). All the previously mentioned rock units are dissected by numerous mafic and felsic dykes which have mainly NWSE, NE-SW and nearly E-W directions. Faults traversing the area are limited and are either concomitant with wadis and drainage lines or cutting through the country rocks. They are of variable length $(1-10 \mathrm{~km})$ and width $(5-500 \mathrm{~m})$ and are steeply dipping. They are mainly of strikeslip type (sinistral or dextral).

Generally, the area of study is characterized by rugged topography due to the presence of moderate to very high mountains. The highest elevation points are represented by Gabal Abu Furad and Gabal Um Tagher younger granites (1032 and $903 \mathrm{~m}$ above sea level, respectively). The area (like all the Red Sea Hills of Egypt) is characterized by arid climatic conditions and very rare vegetation.

The younger granites are characterized by the presence of numerous pegmatitic bodies mainly of unzoned type, while zoned pegmatites are located at the higher elevations. Pegmatites are strongly related to the younger granites, but some of them are recorded invading the older granitoids especially on the peripheral zones of the granitic masses. The pegmatites occur as pockets, lenses or small veins. They are of limited dimension not exceeding $40 \mathrm{~m}^{2}$. The pegmatites are abundantly encountered at the northern and eastern parts of G. Abu Furad granitic mass and at different elevations.

Uranium and thorium are the main radioactive elements in the pegmatite bodies. Their high concentration being a result of late magmatic processes. In the area of study, the accessory and secondary minerals identified in the investigated zoned and unzoned pegmatites by XRD technique can be divided into three main classes:

1. Non-radioactive minerals such as martite, rutile and calcite.

2. Radioactive minerals such as; carnotite, curite, thorianite, zircon and euxenite.

3. Rare-earth radioactive minerals such as bastanaesite, allanite and fluorite.

The present study is concerned with the studies of fluid inclusions of the alteration zone of zoned pegmatites of the G. Abu Furad area, in 
order to estimate the physicochemical conditions of the alteration processes.

\section{Distribution of $U$ and $T h$ in the Unzoned Pegmatites and their Host Granitic Rocks}

In the present work, the $\mathrm{U}$ content was chemically determined using U-lazer analyzer technique. Thorium was colour-metrically estimated using spectrophotometric techniques. All the previously mentioned analyses were carried out in the laboratories of the Nuclear Materials Authority of Egypt.

The unzoned pegmatites are associated with the younger granites. At the periphery of the younger granites, pegmatites occur in a great number of large lenticular or circular pockets. The size of pegmatites varies from few centimeters to about $15 \mathrm{~m}$ in length; with more or less $20 \mathrm{~cm}$ thickness. They are also encountered within the younger granites themselves as small pockets. The pegmatites at the periphery of the younger granites are nearly structurally controlled as they are arranged in more or less one trend along the fractured and sheared zones with a major fault striking NW-SE. They are mainly composed of inter-growth of milky quartz and reddish pink K-feldspar with or without mica, which is mainly represented by muscovite and subordinate biotite. All pegmatite pockets and sheets show more than twice the radioactivity level of the host rocks.

The U-contents in the Abu Furad younger granites range between 19 and $37 \mathrm{ppm}$ with an average $27.8 \mathrm{ppm}$ (Table 1 and Fig. 2). Generally, the uraniferous granites possess U-contents greater than $19 \mathrm{ppm}$ (Assaf et al., 1997; Ahmed and Moharem, 2003 and Salman et al., 2003); thus, Abu Furad younger granites could be considered as uraniferous granites. On the other hand, the pegmatites show higher contents of uranium relative to younger granites. In general, the studied pegmatites can be grouped into two types:

1. Pegmatites distributed within Abu Furad younger granites themselves. Uranium content ranges from 44 to $96 \mathrm{ppm}$ with an average $61 \mathrm{ppm}$. Moreover Th content ranges between 29 and $38 \mathrm{ppm}$ with an average $32.3 \mathrm{ppm}$. Generally, the average of $U$ and $T h$ is higher than $U$ and Th of uraniferous pegmatites given by Ford (1982) and Egyptian 
uraniferous pegmatite given by Heikal et al. (2001), the comparison is shown in Table 1.

Table 1. Uranium and thorium contents in the studied younger granites and the associated unzoned pegmatites of the studied area.

\begin{tabular}{|c|c|c|c|c|c|}
\hline & Rock type & Sample no. & $\mathbf{U}$ & Th & Th/U \\
\hline & & 1 & 19 & 23 & 1.21 \\
\hline & Syenogranites & 2 & 24 & 31 & 1.29 \\
\hline & & 3 & 30 & 39 & 1.26 \\
\hline & & 4 & 37 & 42 & 1.14 \\
\hline & & 5 & 20 & 25 & 1.25 \\
\hline & & 6 & 25 & 30 & 1.20 \\
\hline & & 7 & 32 & 40 & 1.25 \\
\hline & & 8 & 35 & 40 & 1.42 \\
\hline & & Average & 27.75 & 33.75 & 1.25 \\
\hline & Pegmatites within the & 9 & 56 & 32 & 0.57 \\
\hline & younger granites & 10 & 44 & 30 & 0.68 \\
\hline & & 11 & 48 & 29 & 0.60 \\
\hline & & 12 & 96 & 38 & 0.40 \\
\hline 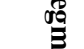 & & Average & 61.0 & 32.3 & 0.56 \\
\hline$\stackrel{\ddot{B}}{*}$ & Pegmatites at the & 13 & 49 & 40 & 0.82 \\
\hline 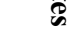 & periphery of the younger & 14 & 46 & 45 & 0.98 \\
\hline & granites & 15 & 36 & 33 & 0.92 \\
\hline & & 16 & 37 & 35 & 0.95 \\
\hline & & Average & 42 & 38.25 & 0.92 \\
\hline Avera & uraniferous pegmatites af & (1982) & 28.6 & 21.4 & 0.74 \\
\hline $\begin{array}{l}\text { Avera } \\
(2001)\end{array}$ & Egyptian uraniferous peg & after Heikal et al. & 45.62 & 36.38 & 0.79 \\
\hline
\end{tabular}

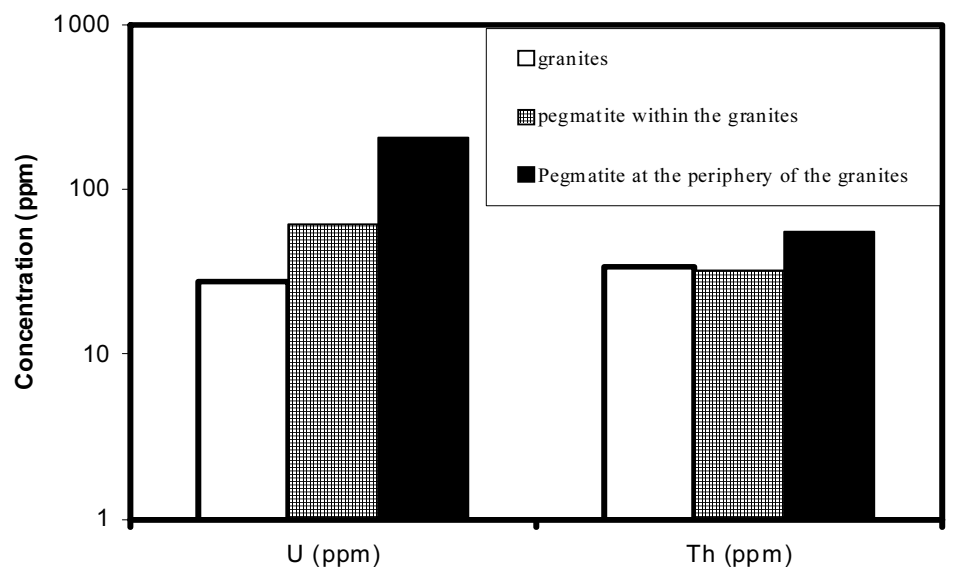

Fig. 2 . $U$ and Th concentration of the studied younger granites and pegmatites. 
2. Pegmatites located at the periphery of the younger granites. The $U$ content varies from 36 to $49 \mathrm{ppm}$ with an average of $42 \mathrm{ppm}$, while the Th content varies from 33 to $45 \mathrm{ppm}$ with an average of $38 \mathrm{ppm}$. These high values reflect primary sites for radioactive elements.

\section{Distribution of $\mathbf{U}$ and $\mathbf{T h}$ in the Zoned Pegmatites}

Zoned pegmatites are strongly related to the younger granites, but some of them are recorded invading the older granitoids especially on the peripheral zones of the granitic masses. Generally, the pegmatites are abundantly encountered at the northern and eastern parts of G. Abu Furad granitic mass and at different topographic levels. They are composed of extremely coarse-grained milky quartz core, intermediate mica zone and wall zone of feldspars. The alteration zone is found in contact between quartz core and intermediate zone. It records the highest radioactive values due to its mineral composition, as a result of alteration processes associated with radioactive minerals.

Uranium and thorium distributions in the zoned pegmatites determined in the wall zone, intermediate zone and altered zone (Table 2 ). It is observed that there is a systematic pattern for $U$ and $T h$ distributions within the different zones (Fig. 3). It is clear from this figure, that $\mathrm{U}$ and $\mathrm{Th}$ decrease from crosscut secondary altered zones toward wall zones. In the wall zone, the average of $U$ content is $57 \mathrm{ppm}$, while Th average content is $50 \mathrm{ppm}$. These values reflect primary sites for the two radioactive elements where zircon, allanite and apatite are the main accessory minerals in this zone.

Table 2. $\mathrm{U}, \mathrm{Th}$ and $\mathrm{Th} / \mathrm{U}$ for the different zones of the studied zoned pegmatites.

\begin{tabular}{|l|c|c|c|c|c|c|c|c|c|}
\hline & \multicolumn{3}{|c|}{ Wall zone } & \multicolumn{3}{c|}{ Intermediate zone } & \multicolumn{3}{c|}{ Alteration zone } \\
\cline { 2 - 10 } & $\mathbf{W}_{\mathbf{1}}$ & $\mathbf{W}_{\mathbf{2}}$ & Average & $\mathbf{M}_{\mathbf{1}}$ & $\mathbf{M}_{\mathbf{2}}$ & Average & $\mathbf{P}_{\mathbf{1}}$ & $\mathbf{P}_{\mathbf{2}}$ & Average \\
\hline $\mathrm{U}$ & 50 & 64 & 57 & 133 & 167 & 150 & 277 & 233 & 250 \\
\hline $\mathrm{Th}$ & 44 & 25 & 50 & 111 & 129 & 120 & 252 & 168 & 210 \\
\hline $\mathrm{Th} / \mathrm{U}$ & 0.88 & 0.81 & 0.87 & 0.83 & 0.77 & 0.80 & 0.91 & 0.75 & 0.84 \\
\hline
\end{tabular}




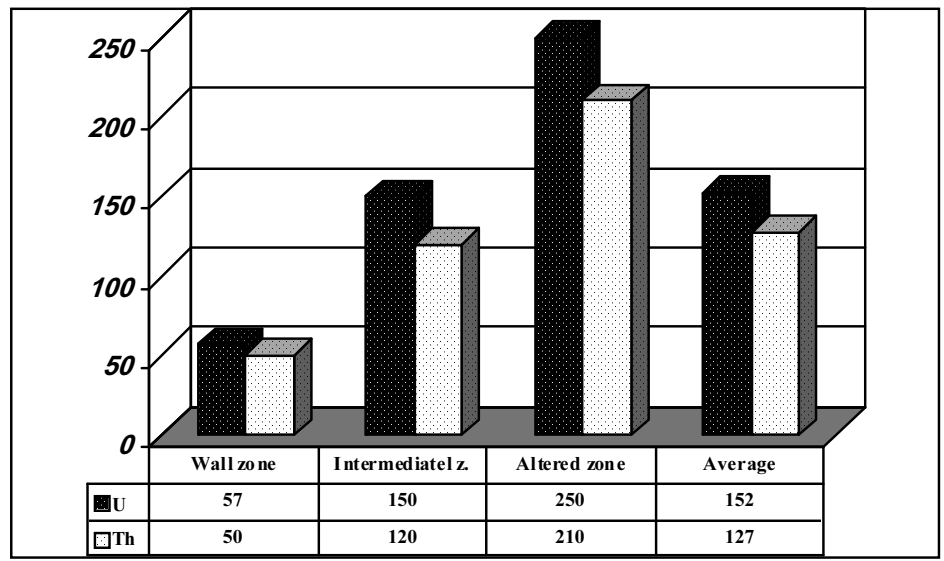

Fig. 3. Average of $U$ and $T h$ distribution in different zones of pegmatites.

The intermediate zone is the most suitable host zone for radioelements with progressively fewer occurrences noted in the secondary alteration zone. The average of both $U$ and Th are $150 \mathrm{ppm}$ and $120 \mathrm{ppm}$ respectively. The high $\mathrm{U}$ and $\mathrm{Th}$ content is due to primary magmatic radioactive minerals and alteration products due to fractionation, hydrothermal activity and weathering.

The alteration zone represents the most quoted host for the radioelements. The average of uranium content in the alteration zone is 250 ppm, while Th average content is $210 \mathrm{ppm}$. The enrichment in both radio-elements exhibit extensive replacement of primary mineral phases by secondary phases produced during late-stage hydrothermal activity that have been accentuated through microfracturing in the host granite. Secondary products include chlorite-replacing biotite, ferruginous clays replacing biotite and calcic plagioclase, and also hematitization as a result of chlorite alteration to carbonate (calcite) and clay minerals. This alteration has increased the radio-element contents.

\section{Fluid Inclusion}

Fluid inclusions are tiny cavities containing liquid, gas and/or solids. In granitic rocks, fluid inclusions are especially common in quartz mineral. The fluids trapped in quartz can either represent the earliest fluids from the cooling magma or later fluids developed during 
hydrothermal circulation. Both types of fluids developed may be trapped in apparently unaltered samples of rock (Roedder, 1979) and it can prove exceedingly difficult to find a sample where the inclusion population only represents the magmatic fluid phase.

Fluid inclusion studies by micro-thermometry were carried out on authigenic minerals (such as quartz and fluorite) in alteration zones (primary fluid inclusions). This study revealed that, at least two stages of post-magmatic hydrothermal alteration were involved. The first stage is of high temperature, low saline fluids that characterized hematitization resulting from fluid-rock interaction with late magmatic fluids that very probably mixed with external low salinity fluids along brittle structure. The second stage is of low temperature high saline fluids that characterized the fluoritized alteration due to consequent reaction with wall rocks and mixing with meteoric water.

\section{Methodology}

Representative four fluorite and quartz samples were chosen for fluid inclusion studies. These samples were collected from the alteration zones (P1 and P2) in the studied zoned pegmatites. The microthemometric measurements on authigenic minerals formed during alteration were carried out in order to estimate physico-chemical conditions of alteration. Doubly polished thin sections of selected sample $(250-300 \mu \mathrm{m})$ were prepared. Freezing/heating microthemometric measurements were carried out using a fluid inclusion adopted USGS gas flow heating/freezing stage emanated to petrographic microscope, at Faculty of Science, Cairo University, Egypt.

Homogenization temperature (Th) is the temperature at which the gas bubble disappears. All inclusions in the studied samples homogenized to the liquid phase. Freezing run to $-90^{\circ} \mathrm{C}$ followed by heating one enable us to record melting temperature (Te). The final ice melting temperature (Ti) enables calculations of fluid inclusion salinities. Table 3 shows $\mathrm{Th}, \mathrm{Ti}$, Te and salinity values of the alteration zone of mineralized pegmatites (P1 and P2). Figure 4 shows the $\mathrm{Th}^{\circ} \mathrm{C}$ versus salinity for fluid inclusions in the studied samples. 
Table 3. Average of microthermometric measurements in the studied samples.

\begin{tabular}{|l|c|c|}
\hline \multicolumn{1}{|c|}{ Temperature $^{\mathbf{0}} \mathbf{C}$} & Quartz & Fluorite \\
\hline $\mathrm{Th}$ & $84.3: 113.1$ & $96.6: 132.1$ \\
\hline $\mathrm{Te}$ & $-30.4:-40.5$ & $-26.3:-31.4$ \\
\hline $\mathrm{Ti}$ & $-1.1:-3.2$ & $-1.5:-2.1$ \\
\hline Salinity (Wt. \% $\mathrm{NaCl}$ eq.) & $1.5: 4.0$ & $2.8: 4.0$ \\
\hline
\end{tabular}

\section{Fluid Inclusion Petrography}

Fluid inclusion studies of the investigated quartz and fluorite were conducted to elucidate the ore genesis and chemical characters of mineralyzing solutions. They also allow us to depict the hydrothermal activities, acting on the studied pegmatites. It is possible to define two different ore-forming solutions. The first one is marked by low salinity, hot circulating solutions, while the second is marked by medium salinity.

Fluid inclusions are abundant in quartz and fluorite samples. A small number of fluid inclusions was trapped during the growth of surrounding host crystals and occur as isolated groups, sometimes confined within growth zone of quartz and fluorite crystals and these assumed to be primary. A great number of fluid inclusions is related to fractures and/or cleavage planes, and therefore, these inclusions were assumed to be secondary. Inclusion shapes may vary from negative crystals to subspherical or irregular branched shapes (obviously necked down) and dimensions range from 10 to $20 \mathrm{~mm}$. Primary fluid inclusions in quartz and fluorite minerals are two-phase, water-rich at room temperature, with constant liquid/ vapor ratio at $\sim 95: 5$. No microthermometric evidence of $\mathrm{CO}_{2}$ have been found in any fluid inclusions. The results presented below are referred to the primary fluid inclusions.

Small size of most inclusions in quartz is typical for the low salinity fluid inclusions. However there is great range between the melting temperature (Te) values for inclusions in quartz and fluorite. Te values in quartz range from $-30.4^{\circ} \mathrm{C}$ to $-40.5^{\circ} \mathrm{C}$ coinciding with $\mathrm{Mg}, \mathrm{Na}$ chlorite water system. Te values in fluorite range from $-26.3^{\circ} \mathrm{C}$ to $-31.4^{\circ} \mathrm{C}$ that are much closer to eutectic for chlorite water system containing bivalent 
ions (notably $\mathrm{Ca}$ and $\mathrm{Mg}$ ) than those containing only $\mathrm{NaCl}$ and / or $\mathrm{KCl}$. The Te below $-54.4^{\circ} \mathrm{C}$ of pure system $\mathrm{H}_{2} \mathrm{O}-\mathrm{CaCl}_{2}-\mathrm{NaCl}$ may be explained by metastability (Kally and Turneaure, 1970). The last ice melting temperature (Ti) shows same population. It ranges from $-1.1^{\circ} \mathrm{C}$ to $-3.2^{\circ} \mathrm{C}$ for quartz samples strongly indicate low salinity. Ti for fluorite sample range from $-1.5^{\circ} \mathrm{C}$ to $-2.1^{\circ} \mathrm{C}$ suggesting low salinity of the forming hydrothermal solution. Total salinities deduced from these temperature ranges from 1.5 to 4 eq. wt $\% \mathrm{NaCl}$ (i.e. the amount of $\mathrm{NaCl}$ which would produce an equivalent lowering). All investigated inclusions homogenize into liquid state during heating runs, at homogenization temperature $(\mathrm{Th})$ that represent minimum trapping temperature. Most of homogenization temperature (Th) range from $80^{\circ} \mathrm{C}$ to $140^{\circ} \mathrm{C}$. These values of $(\mathrm{Th})$ for quartz samples range from $84^{\circ} \mathrm{C}$ to $113^{\circ} \mathrm{C}$, while for fluorite samples they range from $96^{\circ} \mathrm{C}$ to $132^{\circ} \mathrm{C}$.

Two types of fluid inclusions were recorded in quartz (primary and secondary). The primary fluids are isolated inclusions (Fig. 5a), having regular and sometimes irregular shapes ranging from 5 to $25 \mu \mathrm{m}$ across. The second type consists of two-phase inclusion of aqueous liquid with 30-50 volume present liquid plus vapor bubble. The fluid inclusions of this type are of secondary origin and most dominant in the quartz veins (Fig. 5b). They displayed lensoid, elongated and sometimes spherical shapes ranging from 2 to $10 \mu \mathrm{m}$ across. They consist of simple two phases $\left(\mathrm{H}_{2} \mathrm{O}\right.$ liquid and $\mathrm{H}_{2} \mathrm{O}$ vapour $)$ aqueous inclusions with small vapour bubble representing 15 to 20 volume percent.

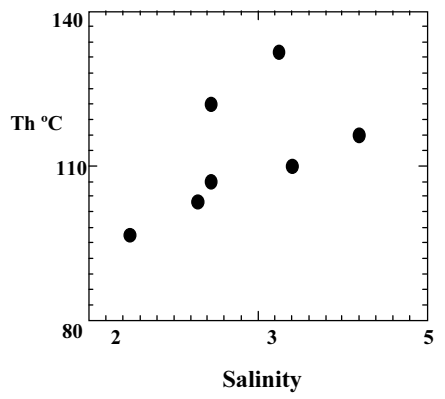

Fig. 4a. Th ${ }^{\circ} \mathrm{C} v$ s. salinity for fluid inclusions in quartz sample.

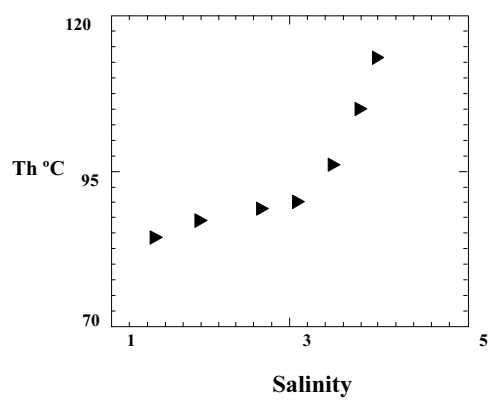

Fig. 4b. Th $^{\circ} \mathrm{C}$ vs. salinity for fluid inclusions in fluorite sample. 


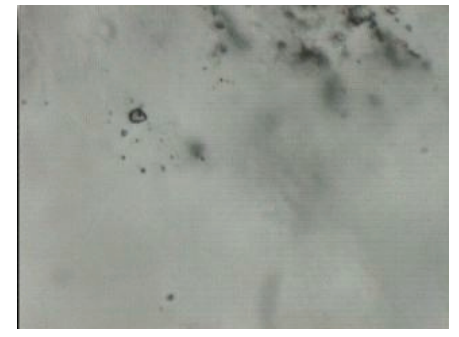

Fig. 5a. Primary fluid inclusion consists of two phases in quartz. O.L. $\mathbf{X}_{150}$.

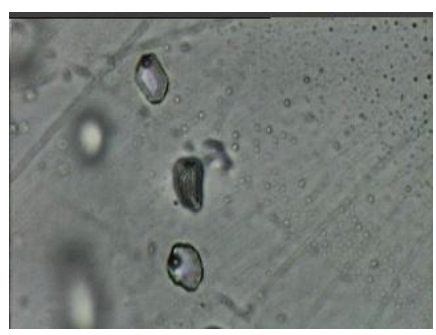

Fig. 5c. Primary fluid inclusion consists of two phases in quartz. O.L. $\mathbf{X}_{150}$.

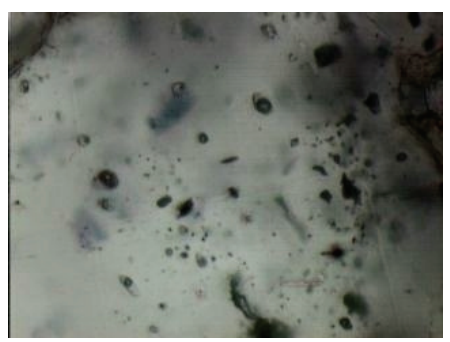

Fig. 5b. Aqueous secondary fluid inclusion in fluorite. O.L. $\mathbf{X}_{150}$.

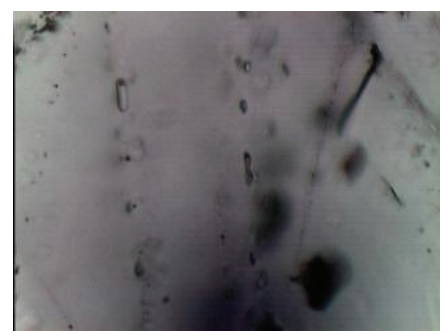

Fig. 5d. Aqueous secondary fluid inclusion in fluorite. O.L. $X_{150}$.

Two types of fluid inclusions were recorded in fluorite (primary and secondary). All the fluid inclusions were homogenized to a liquid phase at 20 to $29.5^{\circ} \mathrm{C}$. The primary inclusions are isolated inclusions, having regular and sometimes irregular shapes ranging from 10 to $30 \mu \mathrm{m}$ across (Fig. 5c). The secondary inclusions are smaller than $10 \mu \mathrm{m}$ across. They are regularly to irregularly shaped as well as slightly surrounded in form, these inclusions are aqueous ones (Fig. 5d). They usually show two phases $\left(\mathrm{H}_{2} \mathrm{O}\right.$ liquid $+\mathrm{H}_{2} \mathrm{O}$ vapor) at room temperature. The vapor phase occupies less than $20 \%$ of the total volume. No minerals were found in these inclusions.

\section{Discussion}

The ascending hot fluids, after being acted on pre-enriched granitic volume, were alkaline and oxidizing when reached the shallow shear zone and caused intensive subsolidus alterations. The evidences of the alkaline nature of the hot-saline fluids are:

1. Precipitation of iron as (hydro) oxides (i.e. hematization) in $\left(\mathrm{P}_{2}\right)$.

2. Limited chloritization of primary silica in $\left(\mathrm{P}_{2}\right)$. 
3. Metamictization of stable accessory minerals such as zircon and allanite in $\left(\mathrm{P}_{2}\right)$ and thorianite in $\left(\mathrm{P}_{1}\right)$.

4. Presence of both carnotite and euxenite in $\left(\mathrm{P}_{2}\right)$. Elevatorski (1978) suggested that, carnotite is associated with all types of hydrothermal solutions, but its colour change according to the type of hydrothermal solution. In strong acidic hydrothermal fluids $(\mathrm{pH}<4)$, carnotite occurs as yellowish brown colour, but in strong alkaline hydrothermal fluids $(\mathrm{pH}>10)$ occurs as cannary yellow colour. In the studied area, carnotite is cannary yellow colour. Accordingly, hydrothermal solution is strong alkaline.

5. Alteration of the allanite by the effect of strong alkaline hydrothermal fluids according to equation given by Abaa (1991) as :

allanite+alkaline fluids $(\mathrm{pH}>12) \rightarrow$ bastenasite + clay minerals + thorianite + martite

The physico chemical conditions of these fluids were ever changing due to consequent reaction with wall-rocks and mixing with meteoric water which leads to low temperature, high saline fluids. Accordingly hydrothermal fluids should have high saline fluids and should have developed a low $\mathrm{pH}$. In these conditions leads to reduction of iron oxide and formation of pyrite and most probably motivated the reduction and fixation of uranium from mineralized hydrothermal solutions.

Rapid cooling or dilution with colder water will cause the solution to become reactive with respect to hydrolytic alteration, boiling will render them inert with respect to this process and will cause deposition of additional calcite, at more shallow depth chlorite and kaoline minerals were deposited. This alteration assemblage is enclosed by rocks affected to varying degrees of alteration caused by interaction with descending recharge of essentially meteoric origin.

Accepting that the removal of solutes and vapor species from the cooling intrusion is a dynamic process. With the respective alteration zones following the advancing front of brittle fracturing to deeper and deeper levels, it is unlikely that the alteration patterns will be preserved in this simple form in actual ore bodies. In addition to the "stretching out" of alteration zones to progressively deeper levels, overprinting and remobilization of components, in response to repeated episodes of intrusive activity and cooling can be expected to lead to the rearrangement of alteration zones to patterns much more complex than 
the monogenetic ones (Kally and Turneaure, 1970; Hammad, 2002 and 2005 and Moharem, 2006).

\section{Conclusions}

The studied area, the younger granites are characterized by the presence of numerous pegmatitic bodies mainly of unzoned type, while zoned pegmatites are located at the higher parts. Abu Furad younger granites are fertile (uraniferous) granites as they possess U-contents greater than $19 \mathrm{ppm}$. Their associated pegmatites show higher U-contents relative to granitoid rocks

Regarding to $U$ and $T h$ evaluation in the study area, pegmatites are the most important types. Zoned pegmatites record higher radioactive levels than unzoned pegmatites. Within the zoned pegmatites, it was noticed that $U$ content decreases from inner zones toward outer zones. The alteration zones recorded the highest $U$ and $T h$ contents due to their mineral composition, as a result of alteration processes (hematization, kaolinitization and fluortization), associated with radioactive minerals (zircon, euxenite, carnotite and thorianite), and rare earth radioactive minerals as (allanite, bastnaesite and fluorite).

Fluid inclusion studies of the investigated quartz and fluorite were conducted to elucidate the chemical characters of hydrothermal solutions. They also allow us to depict the hydrothermal activities, acting on the pegmatites and the host granitic pluton. It is possible to define two different acting solutions. The first one is marked by low to medium salinity, of hot circulating solutions acting under different physicochemical conditions, while the second is marked by high salinity low temperature. The quartz seems to be linked to an early independent hydrothermal event during a reactivation on fracture system, which caused circulation of low salinity hot fluids. Since alteration zones are related to tectonic, variable fluid flux together with change in their physico-chemical potential of the fluid yield fluorite crystallization with variable salinity and temperature. The change in $\mathrm{pH}$ plays the main role in remobilization and precipitation of many rare metals such as $\mathrm{U}, \mathrm{Nb}$, $\mathrm{Zr}$, Th, REE and $\mathrm{Y}$ in minerals assemblage such as euxenite, zircon, thorianite, allanite, bastnesite and Y- fluorite. 
Mixing of low salinity meteoric water with hot ascending saline hydrothermal solution leads to $\mathrm{pH}$ change and continuous interaction with wall rock. Therefore the mechanism of fluorite precipitation is accompanied with a rather complicated series of alteration processes such as hematitization, fluoritization, silicification and kaolinitization. Heating of slightly saline meteoric water by convection acting on the pegmatites along shallow shear zone causes fluorite and uranium mineralization.

\section{References}

Abaa, S.I. (1991) Hydrothermal fluids responsible for the formation of precious minerals in the Nigerian younger granite province, Mineralium Deposita, 26: 34-39.

Ahmed, F.Y. and Moharem, A.F. (2003) Genesis of uranium in the younger granites of Gabal Abu Hawis area, central Eastern Desert, Egypt, Proceedings of the $6^{\text {th }}$ Arab Conf. on the Peaceful Uses of Atomic Energy, Oct. 2003, II: 311-325.

Assaf, H.S., Mahdy, M.A. and El Afandy, A.H. (1997) Egyptian younger granites, an approach to define parameters favouring formation of uranium deposits, $3^{\underline{r}}$ Conference Geochemistry, Alexandria Univ., Egypt. 409-420.

Elevatorski, E.A. (1978) Uranium Ores and Minerals, 88 p., Organized by IAEA.

Ford, K.L. (1982) Uraneferous pegmatites of the Sharbot Lake area, Ontario; in uranium in granites, ed. Y.T. Maurice, Geol Survey of Canada, 81-23, 125-138.

Hammad, H.M. (2002) Geochemistry and radioactivity of Um-Tagher granitic pluton, central Eastern Desert, Egypt, Journal of the Faculty of Education, 27: 60-82.

Hammad, H.M. (2005) Geochemistry and uranium thorium distribution in the Um Samra-Um Bakra granitic plutons and their associated pegmatites, Central Eastern Desert, Egypt, Journal of the Faculty of Education, 30: 50-71.

Heikal, M.T.S., Moharem, A.F. and El-Nashar, E.R. (2001) Petrogenesis and radioactive inspection of Li-mica pegmatites at Wadi Zareib, central Eastern Desert, Egypt, The Second International Conference on the Geology of Africa, Assiut, Oct. 2001, II: 227-305.

Kally, W.C. and Turneaure, F.S. (1970) Mineralogy, paragenesis and geothermometry of the tin and tungsten deposits of the Eastern Andes, Bolivia, Econ.Geol., 65: 609-80.

Moharem, A.F. (2006) Uranium distribution in the mineral constituents of Um Samra-Um Bakra granitic plutons, central Eastern Desert, Egypt, Proceedings of the $7^{\text {th }}$ Arab Conf. on the Peaceful Uses of Atomic Energy, Dec. 2004, II: 111-125.

Roedder, E. (1979) Fluid inclusions as samples of ore fluids. In H.L. Barnes (Ed.), Geochemistry of Hydrothermal Ore Deposits, $2^{\text {nd }}$ edn. Wiley, New York, 684-737.

Salman, A.B., Moharem, A.F., Abdel Warith, A. and Esmail, E.M. (2003) Subsurface geological study of wadi Beli uranium occurrence, north Eastern Desert, Egypt, Al-Azhar Bulletin of Science, Proceedings of the $5^{\text {th }}$ Int. Sci. Conf., 25-27 March 2003, 1-18. 


\section{در اسة المكتنفات السائلة للبجماتيت المتمعدن بمنطقة جبل أبوفير اد، وسط الصحر اء الثرقية، مصر}

\section{عصام محمد إسماعيل، وأشرف فرغل محرم}

هيئة المواد النوويةة، ص ب ، به المعادى، القاهرة، مصر

المستخلص. تسجل الأنواع العديدة من الجيوب البجماتينة (النطاقية

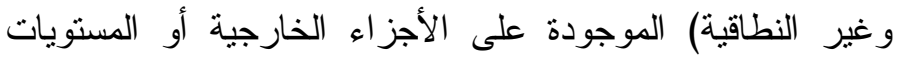

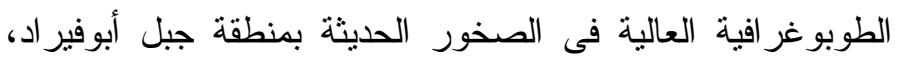

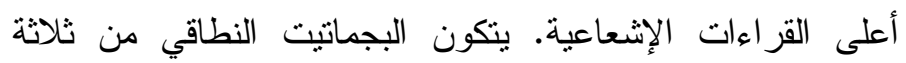
نطاقات (نطاق لبى ونطاق منوسط ونطاق خارجى). يوجد بين

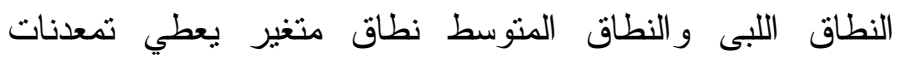
لليور انيوم كنتيجة لوجود معادن إثعاعية مصاحبة لعمليات التغير .

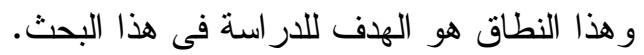

نتيجة تأثير عمليات التغير (التغير بفعل الحديد، و التغير بفعل الفلورين، والتغير بفعل الكاولين) على النطاق المتغير بيتكون

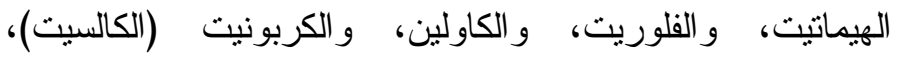

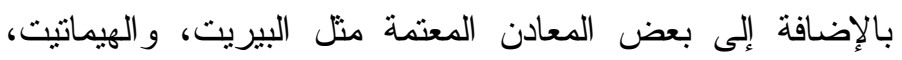

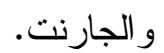

أثتتت دراسة المكتنفات السائلة على معدني الكوارتز و الفلوريت بنطاق التغير أن هناك مرحلنين على الأقل من التغيرات

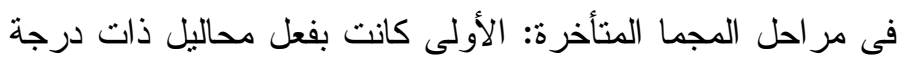
حرارة عالية، وملوحة قليلة، وتتميز بوجود الهيماتيت كنتيجة لعمليات التغير بفعل الحديد، وتتتج هذه المحاليل من تفاعل سو ائل ومله الصخور مع سوائل المجما المتأخرة، التى عادة ما تكون مختلطة 
مع سوائل قليلة الملوحة حول الكسور الضعيفة. النوع الثانى بفعل محاليل ذات درجة حرارة قليلة، وملوحة عالية، وتتميز بتكوين الفلوريت، كنتيجة لعمليات التغير بفعل الفلورين.

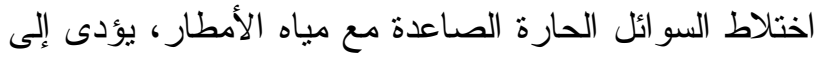

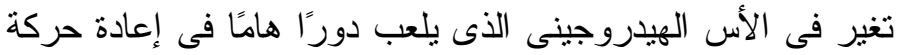

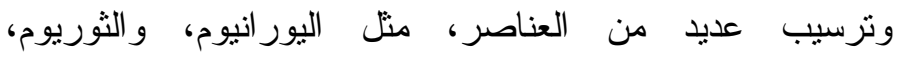

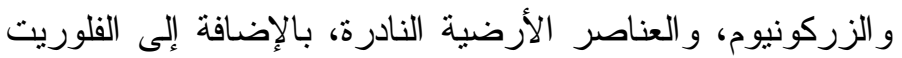

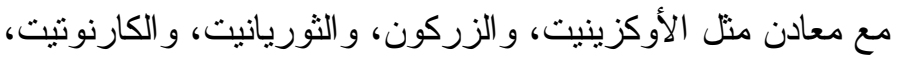 و الألنيت، و البستنزيت، و والفلوريت. 